\author{
Review Article
}

\title{
IMMUNOTHERAPEUTIC EFFECT OF RASAYANAS IN CANCER: A CONCEPTUAL STUDY
}

\author{
Dhatri Datta1*, Jayanthi. C2, Santhosh Patil3 \\ *1PG Scholar, 2Professor \& HOD, Department of Kaya Chikithsa, Ashwini Ayurvedic College and PG Centre, \\ Davanagere, Karnataka.
}

${ }^{3}$ Assistant Professor, Department of Agada Tantra, B.M.K Ayurveda Mahavidyalaya, Belagavi, Karnataka, India.

\begin{tabular}{l|l}
\hline $\begin{array}{l}\text { Article info } \\
\text { Article History: }\end{array}$ & $\begin{array}{l}\text { ABSTRACT } \\
\text { The natural repertory of the normal human immune system's NK and T cells, as well as } \\
\text { Revised: 10-12-2021 } \\
\text { Accepted:22-12-2021 }\end{array}$ \\
$\begin{array}{l}\text { KEYwORDS: } \\
\text { Cancer, Immune } \\
\text { system, Rasayana } \\
\text { Chikitsa, }\end{array}$ & $\begin{array}{l}\text { malignancies, on the other hand, are selected by the host immune system's death of } \\
\text { sensitive tumour cells and the survival of immune-resistant cancer cells. The capacity of } \\
\text { these cells to evade "normal" immune killing actions could be a primary cause of } \\
\text { malignancy progression, resulting in clonal growth, metastases, and patient death. The } \\
\text { Ayurvedic idea of Vyadhikshamatwa, Immunity) which re-engages the immune system to } \\
\text { stage a counter-revolution, lays the path for a considerable clinical improvement in overall } \\
\text { survival of patients with enhanced quality of life. Strategies like Rasayana Chikitsa can help } \\
\text { to boost attempts to remove immune suppression in tumours by rousing dormant T-cell } \\
\text { activity and restoring immune surveillance, especially when combined with chemotherapy } \\
\text { and radiotherapy. The study uncovers aspects of cancer, immunotherapy, Ayurvedic } \\
\text { aspects of Immunity and evidence of Immunotherapeutic properties of Rasayanas. } \\
\text { Immunostimulatory immunotherapy, such as Rasayana Chikitsa, is the focus of this work } \\
\text { which could show to be highly effective by restoring the patient's inherent immune powers, } \\
\text { opening up a new therapeutic front in the clinical arena of Cancer. Although the clinical } \\
\text { studies are limited, the present study hope towards more approvals and wider usage of } \\
\text { Rasayana Chikitsa in Cancer. }\end{array}$ \\
\end{tabular}

\section{INTRODUCTION}

Cancer is a cellular behavior disorder characterized by a loss of structural and functional integrity. Immunotherapy, which is currently one of the hottest fields of cancer research, is built on precision medicine. As part of its normal function, the immune system finds and destroys abnormal cells, which most likely prevents or slows the progression of many cancers. Cancer cells have developed strategies to evade being destroyed by the immune system. For example, may have genetic mutations that make them less detectable to the immune system.

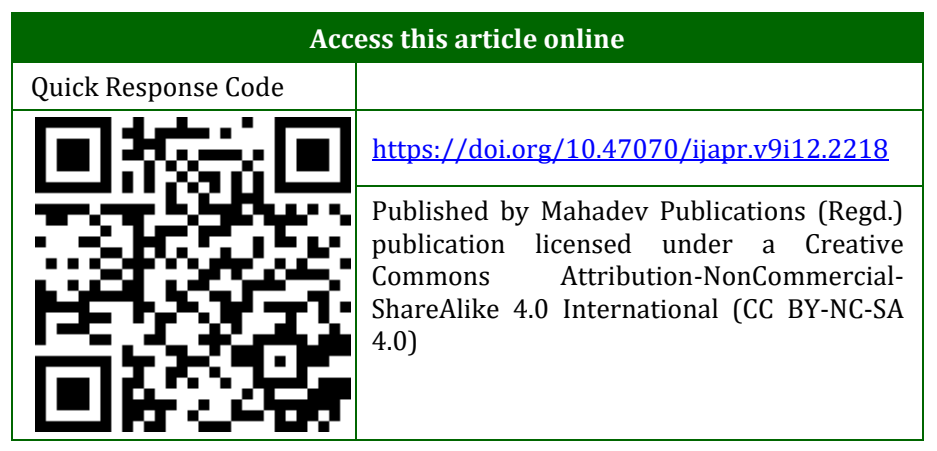

On their surface are proteins that induce immune cells to stop working. Change the normal cells in the tumor's environment so that they obstruct the immune system's response to the cancer cells. [1]

Since it finds reference in the age-old Indian medical expertise -"Ayurveda," a definitive strategy to the understanding and hence rational therapy of immunological illnesses has remained elusive. Ayurveda emphasizes the development of health through the enhancement of host defenses, which serve as a barrier against everyday physiological extremes as well as opportunistic diseases. "Vyadhikshamatwa" (immunity) is the force to be reckoned with when it comes to everyday wellness. The notion of immune-stimulation, which has been outlined in Ayurvedic literature, can be used to treat pathological illnesses that cause a damaged immune system, such as cancer. Acharyas recommended the use of Rasayana to strengthen this Vyadhikshamatwa. Rasayanas are health-promoting as well as revitalizing agents that, via their empirical effects, create physical and mental resistance to disease. It is a treatment that 
prepares the body's constituents to adapt to a specific tissue endowment programme. In modern scientific terms, this idea refers to the augmentation of an organism's immune reactivity to infections by nonspecifically activating the immune system with immunomodulatory drugs. Rasayana's activity might be understood in modern terms like: nutritional function, immunomodulatory, antioxidant, anti-aging, neuro-protective, haemopoietic effect, and so on.

\section{Cancer and Immunotherapy}

Cancer: Traditionally, cancer has been treated with surgery, chemotherapy, and radiation therapy. Despite significant advancements in these treatments over the last decade, radiation or chemotherapy can only destroy a small percentage of tumor cells, with a high amount of cytotoxicity towards healthy cells as a side effect.[2] Despite the fact that surgery is helpful in curing cancer, it is limited to benign and circumscribed metastases, which account for only $10-15 \%$ of cases of Cancer.[3] Traditional anti-cancer medicines have serious side effects due to their lack of selectivity, as a proclivity for producing drug-resistant cancer cells. ${ }^{[4]}$

Immunotherapy: Cancer immunotherapy aims to create drugs that trigger or enhance the immune system's detection and destruction of cancer cells. [5] Recent research has found evidence that the immune system can truly inhibit tumour growth. Certain tumours have been shown to spontaneously retreat, resulting in greater health for the patient in neuroblastoma, renal cell carcinoma, lymphomas, leukaemia, and malignant melanoma. ${ }^{6]}$ The reason is that the individual's immune system gets stimulated in an unanticipated way, causing non-self-proteins to be recognized and cancer cells to be destroyed that allows researchers to study and create treatments for future sufferers.[7] Some patients have shown spontaneous antibody responses to autologous malignancies.[8,9] There have also been reports of $\mathrm{T}$-cell responses associated with melanoma regression having been the best evidence linking an immune response that have been documented.[10-12]

\section{Ayurvedic Outlook on Immunity}

In Ayurveda, the wide idea of Vyadhikshamatwa encompasses the modern concept of immunity. Vyadhikshamatwa refers to the process of preventing disease development as well as the ability to resist disease.[13] Chakrapani describes it in two ways: Vyadhi Bala Virodhitva (hostile to disease strength and virulence) and Vyadhi Utpadaka Vibandhakatva (the ability to limit, contain, or bind illness causes and factors), which prevents disease during the Samprapti (pathogenesis). This is actually the avoidance of sickness from manifesting. ${ }^{[14]}$
Ayurvedic Concept of Immune Tolerance and Autoimmunity

The Tri Doshas, regardless of their opposing features, coexist in a healthy body in a normal stage. This is known as Sahaja Satmya, (the immunological tolerance). This is the reason why the body's own immune cells do not attack itself. However, due to the influence of Daiva (preceding or unknown factors) or Svabhavika Karanas (possible mechanisms of commencing autoimmune reaction like microbial, genetic, or immunological) possibly paving way to mismatch the Sahaja Satmya, thereby, immune cells (leucocytes) lose the ability to fight infection.[15]

Vata Pradhana lakshanas are mentioned in the literature like Alpasmruti (lesser recollection-anomaly to WBCs) and Sheegra Grahita (early identification of tissue). The Characteristics indicated, occur at the Rakta level, that is, at the level of WBCs in the recognition of bodily tissues. This mechanism causes the body tissues to be misunderstood as an external antigen.

Pitta Pradhana Lakshana, like Teekshna Guna, leads to Teekshna Agni and Parakrama. This triggers an immune system attack on the body's own tissues, by a series of aberrant and unpleasant reactions. This is Ojovisramsa (Dosha dysfunction), as well as the malfunctioning and relocation of Doshas.

Prakupita Vata and Pitta, leads to decline in Kapha or the formation of Malarupi Kapha (altered leucocytes). Balakruta is the synonym of Kapha Dosha, which might be regarded as Slaishmika or Apara Ojas that bestows Vyadhikshamatwa. Ojas is the essence of all Moortimat Dhatus and is a material (The white portion of blood - WBCs or leucocytes), while Bala is the functional output. Even though Vata and Pitta have their own roles in judgment and attack, both are controlled by Kapha Dosha. When Anya Dosha (besides Kapha Dosha) Prakopa occurs, it results in Kapha kshaya (altered leucocytes) or Malarupi Kapha (modified leucocytes), resulting in immune system dysfunction.

\section{Concept of Rasayana}

Ayurveda recommends a daily regimen, seasonal regimen, dietary code of conduct, social behaviour code, Rasayana Chikitsa to maintain and preserve health. Rasayana is one of Ayurveda's broad disciplines, to accomplish the best possible state of the body's tissues and systems, with the least effect of etiological factors. According to new evidence, possible mechanisms include immunostimulation, tempering free radicals, boosting cellular detoxification mechanisms, repairing damaged non-proliferating cells, initiating cell proliferation and self-renewal of deteriorated proliferating tissues, and regenerating them by replacing damaged or deformed cells with fresh cells.[16] 
The word Rasayana is made up of two words 'Rasa' and 'Ayana', which refers to a method of obtaining good quality Rasa in the body for circulation. The status of this Rasa in the body has a direct impact on an individual's health, hence achieving the highest level of Rasa is known as Rasayana.

\section{Mode of Action of Rasayana Drugs}

All Rasayanas are Ojovardhaka, which means they improve immunity, whose action has been debated for a long time and its effect regarded by many scholars as the Prabhava (particular therapeutic effect) of the treatments. Rasayanas have the following effects: ${ }^{[17]}$

1. At the Level of Rasa- It boosts specific nutritional properties of Poshaka Rasa, the tissue plasma that aids in the attainment of the greatest attributes of all Dhatus. Madhura, Guru, Snigdha, and Sita are all properties of such drugs.

2. At the level of Agni- Some Rasayanas act on digestion and metabolism, rejuvenating the structural and functional arrangement of tissues, contributing to activation of Dhatvagni, resulting in excellence of all Dhatus. Usna, Laghu, Ruksha, Katu, Tikta, and Kashaya Rasa are examples of such drugs.

3. At the level of Srotas (Microchannels)- Improves the bioavailability of nutrients to the tissues and tissue perfusion, resulting in Srotoshodhana. The drugs possess Katu, Tikta, and Kashaya Rasa, Vishada, Ruksha, and Laghu guna, Katu vipaka and Usna veerya.

4. At the level of Ojas- Certain Rasayanas, Such as Jeevaniya Gana, have a direct influence on the better creation and functioning of bio-immune strength, which induces Bala and Vyadhikshamatwa in the individual.

\section{Evidences for Immunotherapeutic Properties of Rasayanas}

1) Rasayana As Anti-Oxidants- The anti-oxidant mechanism appears to be regulated by bodily elements such as the optimal quality of Rasa dhatu, Kapha Dosha, and Ojas.[18] The ability of Rasayanas is assessed by control of oxidative stress and prevention of cellular damage. As a result of metabolism, free radicals and reactive oxygen species are produced. They are very reactive and can inflict more harm. Cellular damage and illnesses are caused by excessive buildup. Antioxidants scavenge these free radicals and reactive oxygen species and render them harmless.[19] In vitro, Rasayanas are effective scavengers of superoxide, hydroxyl, and nitric oxide radicals, as well as regulators of lipid peroxidation. ${ }^{[20]}$

The mode of action of Ayurvedic anti-oxidants was researched by Devasagayam's group at Bhabha Atomic Research Centre. They discovered that
Ayurvedic medicines can have anti-oxidant effects at various levels:[21]

Level of Suppression of radical formation, Level of Scavenging of Primary radicals, Level of Scavenging of Secondary Radicals, Level of Reconstitution of membranes, Level of Repair of damage.

2) Adaptogenic Activity- Can be attributed to Sthira (stable), Guru (heavy), Sheeta (cold) potency. These characteristics contribute to stability, enhanced endurance, and the ability to halt responses. Kapha Dosha exhibits all three features, whereas Vata Dosha demonstrates the opposite traits. Adaptogens can function as a pro-Kapha and Vata stabilizer.[18]

3) Nutraceutical Effect- Rasayanas can improve digestion and microcirculation at the cellular level.[19] They have been proven to have tissue and disease specific immunomodulatory properties, as well as promoting or restoring functional immunity. It may also help to produce a micro environment in which a cell or tissue may develop properly. ${ }^{[22]}$

4) Nootropics (Cognition Enhancers)- The medhya Rasayana herbs, which support cognitive and memory processes, can be used as nootropics. They are thought to boost the performance of existing brain synapses (adaptive capacity). This mitigates negative effects such as energy and neurotransmitter metabolic abnormalities, as well as ischemia.[23] Nootropics improves Dhi (intellect), Dhriti (restraint), and Smriti (memory). This indicates that the Rasayana has a Vata-Pitta stabilizer and a pro- Kapha profile.[18] Rasayana medications may also have an effect on stem cells. Nestin is an early marker of neural stem cell development when stem cells are treated with Medhya rasayana medicines.[24]

5) Anabolics- Is triggered by certain Rasayana drugs. They encourage development by promoting nucleic acid synthesis and protein metabolism. The Rasayana herbs in the Jeevaniya, Vayasthapana group can help with Balya (strength), Pushti (bulk), and Brimhana (nutrition). [25]

6) Rasayana as Immunomodulator- Rasayanas are unique among immunomodulating agents which activates immune function without affecting the body's other basic parameters. The overall number of leukocytes, absolute number of polymorphonuclear cells, and lymphocytes in the peripheral blood of mice improved after Rasayana administration. ${ }^{[26]}$ This enhancement did not exceed the normal range of respective cells in the peripheral blood, unlike cytokines.[27] or other immunomodulators.[28] Other haematological parameters were not affected by Rasayana treatment.[29,30] Human investigations bolstered the findings of the animal experiments. ${ }^{[31]}$ 
The administration of Brahma Rasayana did not result in substantial increase in total leukocyte or absolute counts of various WBCs or other haematological parameters, but it did result in a considerable functional boost of lymphocytes, which was an unexpected outcome. In addition, serum Granulocyte-Macrophage Colony-Stimulating Factor (GM-CSF) levels increased somewhat in participants. This shows that Rasayana treatment retains basic parameters consistent with the physiology and body constitution of the treated species while also keeping the system watchful and awake to protect it from harmful stimuli.[31] Rasayanas increased NK cell activity and ADCC in tumor-bearing rats relatively early compared to untreated tumor-bearing controls, suggesting that one of the mechanisms of tumour reduction and dissemination may be heightened immune activities within the host as a result of tumour challenge. Rasayanas increased the production of IL-2, IFN-, and GM-CSF, suggesting that cytokines may play a role in tumour decrease. ${ }^{[32]}$

7) Induction of Tissue Cell Proliferation and SelfRenewal - When significant levels of cell death occur in the bone marrow as result of a toxic shock, Rasayanas are effective inducers of proliferation. Rasayanas considerably reduced the leukopenia in mice's peripheral blood caused by cyclophosphamide. [32] and radiation. Within 48 hours, leukocyte counts had risen above normal levels, indicating an improved regeneration potential. The effect of Rasayanas on bone marrow cellularity in $\mathrm{CP} /$ radiation-treated rats was very striking. They increased NK-cell activity and ADCC in whole-body irradiation mice several days before it happened in control mice. [33]

As shown by significantly higher leukocyte, neutrophil, and lymphocyte count in patients receiving $\mathrm{CT}+\mathrm{RT}$ and lymphocytes in patients getting RT alone, myeloid recovery was hastened in the Rasayana treated groups compared to untreated individuals. The time it took to get normal leukocyte, neutrophil, beneficial effect on these regulatory systems, activating stem cell proliferation, self-renewal, and differentiation during emergencies.[33]

8) Inhibition of Mutations- Rasayans have been shown to protect mice from methylcholanthreneinduced cancer. ${ }^{[34]}$ The mechanism of this inhibition could be increased detoxification enzyme activity or inhibition of enzymes involved in carcinogen activation. Rasayanas like Emblica officinalis, has been proven to increase tissue levels of drug metabolizing enzymes such glutathione Stransferase (GST) and aniline hydroxylase (AH) while decreasing tissue levels of reduced glutathione.[35]

Rasayanas may work by triggering cell death in damaged and irreparable cells, or by establishing a milieu that induces cell death in mutant cells, or by activating cellular repair processes in repairable cells through unknown methods. If Rasayanas could initiate this process, genetic harm might be prevented from being passed down to future generations due to effective self-screening and elimination of abnormal sperms during spermatogenesis. ${ }^{[36]}$

\section{DISCUSSION}

The major goal of Rasayanas is to strengthen healthy cells, tissues, and diverse body systems while maintaining dynamic equilibrium and homeostasis, which aids in body immunity management. Apoptosis, or programmed cell death, is triggered by balanced immunity. Rasayana therapy has the ability to organically deal with cancer cells in this way. Immune system management also decreases the effects of malignancies on the body, improving patient's quality of life. Using the preceding studies as a foundation, we may deduce the efficacy of Rasayanas as follows:

\section{Rasayana and its Compliance with Other Cancer Therapies}

Rasayana greatly improves patient's tolerance of traditional cancer therapies and reduces the negative effects of Chemotherapy, Radiotherapy and other treatments without interference with their efficacy but rather functions as an adjuvant, helping to improve quality of life, slow cancer progression, and considerably increase overall survival.

\section{Rasayana and Disease Progression}

Rasayana considerably minimizes the likelihood of illness spread and development by strengthening healthy tissues and normal cells by reducing the risk of relapse or metastasis, especially in individuals who have had tumours surgically removed, and is a viable choice in patients who have had a previous relapse or metastasis.

\section{Rasayana and Tumor Response}

Rasayana also aids in the reduction of tumour burden when used in conjunction with chemotherapy and radiotherapy, albeit the result is highly individual.

\section{Rasayana and Quality of Life}

Improvement in quality of life is one of the most important therapeutic effects in cancer patients. Rasayana improves QOL in functional, emotional, and physical realms. This is particularly important in advanced-stage cancer patients for whom a cure is not possible. Rasayana assists such patients in leading a near-normal QOL free of side effects or toxicity. 


\section{Rasayana and Caregiver}

With cancer patients, the caregiver also suffers greatly. It is difficult for them to hospitalize a patient and deal with post-treatment period if the patient's quality of life deteriorates. Rasayana Chikitsa is an oral medication that does not require hospitalization, patient can live almost independently, they are less reliant on caregivers, their quality of life will be considerably improved and maintained even in advanced stages of cancer.

\section{CONCLUSION}

Rasayanas may protect cellular macromolecules from damage, remove old, damaged, or mutant cells, activate cell proliferation in tissues and maintain homeostasis, perform self-renewal, detoxify harmful endogenous and exogenous toxic products, and improve the functions of each cellular component of the defense system. This review may provide insight to validate the immunotherapeutic efficacy of Rasayanas in cancer. The time has come to place a greater emphasis on disease prevention, and hence the current health-care policy will have to address public knowledge of Rasayana. Individual quality of life is important, so Ayurvedic research should focus on identifying key areas of Rasayana application and generating sufficient evidence with guidelines so that it can be included in national health policies and Ayurveda can contribute to the betterment of humanity.

\section{REFERENCES}

1. National Cancer Institute- Immunotherapy for Cancer. [Cited 2019 Sept 24] Available from: https://www.cancer.gov/aboutcancer/treatment/types/immunotherapy

2. Urruticoechea A, Alemany R, Balart J, Villanueva A, Vinals F, Capella G. Recent advances in cancer therapy: an overview. Current Pharmaceutical design. 2010; 16(1): 3-10.

3. Ohlsson B, Stenram U, Tranberg KG. Resection of colorectal liver metastases: 25-year experience. World journal of Surgery. 1998; 22(3): 268-77.

4. Guillemard V, Saragovi HU. Novel approaches for targeted cancer therapy. Current cancer drug targets. 2004; 4(4): 313-26.

5. Sharma P, Wagner K, Wolchok JD, Allison JP. Novel caner immunotherapy agents with survival benefit: recent successes and next steps. Nature Reviews Cancer. 2011; 11(11): 805-12.

6. Papac RJ. Spontaneous regression of cancer. Cancer treatment reviews. 1996; 22(6): 395-423.

7. Papac RJ. Spontaneous regression of cancer: Possible mechanisms. In vivo (Athens, Greece). 1998; 12(6): 571-8.

8. Carey TE, Takahashi T, Resnick LA, Oettgen HF, Old LJ. Cell surface antigens of human malignant melanoma: mixed hemadsorption assays for humoral immunity to cultured autologous melanoma cells. Proceedings of the National Academy of Sciences. 1976; 73(9): 3278-82.

9. Ueda R, Shiku H, Pfreundschuh M, Takahashi T, Li LT, Whitmore WF, Oettgen HF, Old LJ. Cell surface antigens of human renal cancer defined by autologous typing. The Journal of experimental medicine. 1979; 150(3): 564-79.

10. Ferradini L, Mackensen A, Genevée C, Bosq J, Duvillard P, Avril MF, Hercend T. Analysis of T cell receptor variability in tumor-infiltrating lymphocytes from a human regressive melanoma. Evidence for in situ $\mathrm{T}$ cell clonal expansion. The Journal of clinical investigation. 1993; 91(3): 118390.

11. Zorn E, Hercend T. A MAGE-6-encoded peptide is recognized by expanded lymphocytes infiltrating a spontaneously regressing human primary melanoma lesion. European journal of immunology. 1999; 29(2): 602-7.

12. Hanahan D, Weinberg RA. Hallmarks of cancer: the next generation. cell. 2011; 144(5): 646-74.

13. Singh K, Verma B. The concept of vyadhikshamatva (immunity) in Ayurveda. Ayurpharm Int J Ayur Alli Sci. 2012; 1(5): 99-108.

14. Kulkarni A. Concept of Vyadhikshamatva In Ayurveda. International Journal of ResearchGranthaalayah. 2020; 8(8): 239-43.

15. Krishnan RN, Mohan N. Concept of Vyadhikshamatva with special reference to Immune tolerance and Auto-Immunity. Journal of Ayurveda and Integrated Medical Sciences. 2016; 1(01): 68-72.

16. Goyal M. Rasayana in perspective of the present scenario. Ayu. 2018; 39(2): 63.

17. Byadgi PS, Pandey AK. A text Book of Kayacikitsa. Reprint ed. Chaukambha Sanskrit Sansthan; Varanasi. Vol. III. A Detail Description of Rasayana Cikitsa \& its Therapeutic Modalities. 2020. p. 9212.

18. Deole YS, Thakar AB, Chandola HM, Ravishankar B. Clinico experimental study on role of stress in premature ageing and its management with Rasayana Yoga. Gujarat Ayurved University, Jamnagar, India. 2011.

19. Oza DN, Tanna I, Ravishankar B, Chandola HM. Evaluation of Bhringarajadi Ghrita Rasayana in Premature Ageing. AYU (An international quarterly journal of research in Ayurveda). 2009; 30(2): 109.

20. Jose JK, Kuttan R. Antioxidant activity of Emblica officinalis. Journal of clinical. Biochemistry and. nutrition. 1995; 19(2): 63-70.

21. Vaidya AD, Devasagayam TP. Current status of herbal drugs in India: an overview. Journal of 
clinical biochemistry and nutrition. 2007;41(1):11.

22. Sharma V, Chaudhary AK. Concepts of Dhatu Siddhanta (theory of tissues formation and differentiation) and Rasayana; probable predecessor of stem cell therapy. Ayu. 2014; 35(3): 231.

23. Kulkarni R, Girisha KJ, Kumar A. Nootropic Herbs (Medhya Rasayana) in Ayurveda: A-an update. Pharmacognosy reviews. 2012; 6(12): 147.

24. Joshi KS, Bhonde R. Insights from Ayurveda for translational stem cell research. Journal of Ayurveda and Integrative medicine. 2014; 5(1): 4.

25. Byadgi PS, Pandey AK. A text Book of Kayacikitsa. Reprint ed. Chaukambha Sanskrit Sansthan; Varanasi. Vol. III. A Detail Description of Rasayana Cikitsa \& its Therapeutic Modalities. 2020. p. 925.

26. Kumar VP, Kuttan R, Kuttan G. Effect of "rasayanas", a herbal drug preparation on immune responses and its significance in cancer treatment. Indian Journal of Experimental Biology. 1999; 37(1): 27-31.

27. Lieschke, GJ, Burgess AW. Granulocyte colonystimulating factor and granulocyte-macrophage colony-stimulating factor. New England Journal of Medicine. 1992; 327(2): 99-106.

28. Hadden JW. The Prospects for Immunorestoration in the Treatment of Immuno-Deficiency Arising from Aging or Stress. In Stress, Immunity, and Aging 2020. p. 291-305.

29. Praveen Kumar V, Kuttan R, Kuttan G. Effect of Rasayanas in normal and tumor-bearing mice Journal of Experimental \& Clinical Cancer Research. 1994; 13(1): 67-70.
30. Praveen Kumar V, Kuttan R, Kuttan G. Immunomodulatory and chemoprotective effects of Rasayanas. Proc. Kerala Sci. Congr. 1994; 6: 21921.

31. Joseph CD, PraveenKumar V, Kuttan G, Kuttan R. Myeloprotective effect of a non-toxic indigenous preparation Rasayana in cancer patients receiving chemotherapy and radiation therapy. A pilot study. Journal of experimental \& clinical cancer research: CR. 1999; 18(3): 325-9.

32. Rekha PS, Kuttan G, Kuttan R. Immunopotentiating activity of Brahma Rasayana. Amala Research Bulletin. 1998; 18: 85-90.

33. Kumar P, Kuttan R, Kuttan G. Radioprotective effects of Rasayanas. Indian Journal of. Experimental biology. 1996; 34(9): 848-50.

34. Menon LG, Kuttan R, Kuttan G. Inhibition of chemical induced carcinogenesis by Rasayana-An indigenous herbal preparation. Journal of Experimental \& Clinical Cancer Research. 1996; 15(3): 241-3.

35. Jeena KJ, Joy KL, Kuttan R. Effect of Emblica officinalis, Phyllanthus amarus and Picrorrhiza kurroa on N-nitrosodiethylamine induced hepatocarcinogenesis. Cancer letters. 1999; 136(1): 11-6.

36. Vayalil PK, Kuttan G, Kuttan R. Rasayanas: evidence for the concept of prevention of diseases. The American journal of Chinese medicine. 2002; 30(01): 155-71.

37. Vayalil PK, Kuttan G, Kuttan R. Rasayanas: evidence for the concept of prevention of diseases. The American journal of Chinese medicine. 2002; 30(01): 155-71.

\section{Cite this article as:}

Dhatri Datta, Jayanthi. C, Santhosh Patil. Immunotherapeutic Effect of Rasayanas in Cancer: A Conceptual Study. International Journal of Ayurveda and Pharma Research. 2021;9(12):92-97. https://doi.org/10.47070/ijapr.v9i12.2218

Source of support: Nil, Conflict of interest: None Declared
*Address for correspondence Dr. Dhatri Datta

PG Scholar,

Department of Kaya Chikitsa, Ashwinin Ayurvedic College and PG Centre, Davanagere, Karnataka, India,

Email:

dr.dhatridattabams@gmail.com Phone: 9900361408

Disclaimer: IJAPR is solely owned by Mahadev Publications - dedicated to publish quality research, while every effort has been taken to verify the accuracy of the content published in our Journal. IJAPR cannot accept any responsibility or liability for the articles content which are published. The views expressed in articles by our contributing authors are not necessarily those of IJAPR editor or editorial board members. 